\title{
BANKS, SHORT TERM DEBT AND FINANCIAL CRISES: THEORY, POLICY IMPLICATIONS AND APPLICATIONS
}

\author{
Douglas W. Diamond \\ Raghuram G. Rajan \\ Working Paper 7764 \\ http://www.nber.org/papers/w7764 \\ NATIONAL BUREAU OF ECONOMIC RESEARCH \\ 1050 Massachusetts Avenue \\ Cambridge, MA 02138 \\ June 2000
}

We are grateful for financial support from the National Science Foundation and the Center for Research in Security Prices. This paper was prepared for the Carnegie Rochester Conference on Public Policy. Bruce Smith offered a useful critique. The views expressed herein are those of the authors and not necessarily those of the National Bureau of Economic Research.

(C) 2000 by Douglas W. Diamond and Raghuram G. Rajan. All rights reserved. Short sections of text, not to exceed two paragraphs, may be quoted without explicit permission provided that full credit, including (C) notice, is given to the source. 
Banks, Short Term Debt and Financial Crises: Theory, Policy

Implications and Applications

Douglas W. Diamond and Raghuram G. Rajan

NBER Working Paper No. 7764

June 2000

JEL No. G20, G21, E50, E58

\begin{abstract}
Short-term borrowing has often been blamed for precipitating financial crises. We argue that while the empirical association between a financial institution's, or country's, short-term borrowing and susceptibility to crises may, in fact, exist, the direction of causality is often precisely the opposite to the one traditionally suggested by commentators. Institutions like banks that want to enhance their ability to provide liquidity and credit to difficult borrowers have to borrow short-term. Similarly countries that have poor disclosure rules and inadequate investor protections, have limited long-term debt capacity, and will find their borrowing becoming increasingly short-term as they finance illiquid investment. Thus it is the increasing illiquidity of the investment being financed (or the deteriorating credit quality of borrowers) that necessitates short-term financing, and causes the susceptibility to crises. In fact, once illiquid investments have been financed, rather than making the system more stable, a ban on short-term financing may precipitate a more severe crisis. Even a priori, a ban is not without adverse consequences - policy makers have to trade off the costs of decreased credit creation and investment against the benefits of greater stability. A ban on short-term debt often deals with symptoms rather than underlying causes.
\end{abstract}

Douglas W. Diamond

The University of Chicago

Graduate School of Business

1101 E $58^{\text {th }}$ Street

Chicago, IL 60637

and NBER

d-diamond@uchicago.edu
Raghuram G. Rajan

The University of Chicago

Graduate School of Business

1101 E $58^{\text {th }}$ Street

Chicago, IL 60637

and NBER

raghuram.rajan@gsb.uchicago.edu 
Why do financial crises take place? Most responses to this question start with the statement that banks are fragile, and prone to runs. But then why have banks, or if one has to have them, why should they be structured in such a way as to make them liable to implode? Why not finance banks with long-term claims? The reply is usually a ritualistic mumble about how the need for payment services forces banks to have short term liabilities. But this then suggests that banks might be the wrong institution to offer payment services. Why should the illiquid loans that typically constitute bank assets be financed by volatile, first-come-first-served demandable deposits?

The answers to these questions are important because the policy response to a crisis, whether at a large bank or in an entire banking system often seems a response to a symptom rather than the underlying cause. For example, the knee-jerk policy reaction to the recent turmoil in South East Asia has been to blame the build-up of short term foreign debt prior to the crisis, and to call for Chilean style taxes on short-term foreign investment outflows to ensure that only long term investors come in. Those who advocate such policies generally do not focus on why countries borrowed short term before the crisis. But the answer is important to understand whether the cure is worse than the disease.

Consider South Korea. Rodrik and Velasco (1999) compare Korea's experience in 19791980 with its experience in 1997-98 to highlight the adverse role of short-term debt. In the latter half of the 1970s, South Korea borrowed heavily from foreign banks to finance investment. The debt to GDP ratio in 1979 was $31.3 \%$ while it was $34.6 \%$ in 1997 . The current account deficit was 6.4 percent of GDP in 1979, up from 2.2 percent in 1978. The current account deficit was 4.7 percent in 1996, up from 1.9 percent. These deficits reflect, in part, negative terms-of-trade shocks; rising oil prices in 1979-80 and falling semi-conductor prices in 1996-97. In addition, though, the economy faced political turmoil in 1979 as a result of the assassination of President Park, and also pressure from the Volcker induced world-wide hike in interest rates.

Thus, if anything, South Korea may have faced more severe shocks in 1979. Yet there was no crisis then. The reason, Rodrik and Velasco argue, had to do with short term debt. In 
January 1980, Korea's short-term external debt stood at only 8.4 percent of GDP and 97 percent of exchange reserves. By contrast, in late 1997, it stood at 15 percent of GDP and more than 300 percent of reserves. The difference in initial positions mattered tremendously. In 1980, Korea was able to run an even larger current account deficit by relying on short term external borrowing, with short term debt to GDP going up to over 15 percent by the end of the year. The tilt towards short-term financing was "due in part to the hesitation of creditors to commit long-term funds in the face of political and economic uncertainty". By contrast, in 1997, with short-term debt ratios so high, Korea had no room to borrow - "short-term liabilities were an instigator of the crisis and could hardly play the role of savior". Korea had to generate a large current account surplus, with consequent strains on the economy and on growth. Rodrik and Velasco conclude that a large exposure to short-term debt intensifies the cost of a crisis, and call for a flexible approach that works on several fronts of which one "undoubtedly, is increasing liquidity and discouraging short term debt".

We disagree with this last conclusion, for it is at odds with the example the authors themselves provide. Korea survived in 1979 only because it could issue short-term debt. So a blanket discouragement to short-term debt does not seem warranted. More likely, the authors would like the build-up itself to be discouraged in the first place. The important question then is why short-term debt built up prior to 1997-98 but not prior to 1979-80. While distorted regulations may have been partly responsible for the build up of short-term debt immediately prior to 1997-98, the nature of the investments being financed and the lack of investor confidence was probably the primary determinant. As we will argue, a specific bank, or a banking system, is best able to finance illiquid investments - investments that are less likely to produce cash flows in the short run, or have ready secondary market values - with short-term rather than long-term debt. If so, our model suggests the following explanation of the different outcomes. Prior to 1979 , foreign investors had confidence in recovering their money from the kinds of projects South Korea was financing, and were willing to hold medium- and long-term claims. The various political and macro-economic shocks reduced cash flows from these projects and lengthened 
payback periods. As these projects became more illiquid, shorter-term external claims - perhaps intermediated by the domestic banking system -- became the only economic way to finance them. Since short-term debt capacity, which is all that is available for really illiquid projects, had not been exhausted, Korea could keep these projects afloat.

By contrast, in the run-up to 1997-98, more and more loans were being made to small and medium firms that are typically illiquid, and many of these were un-collateralized (see Dooley and Shin (1999)). External investors relied on the domestic banking system to monitor and recover payments from these difficult credits. They themselves could have confidence in recovering their claims from the domestic banking system only if they held short-term debt against the banking system, hence the build up of short-term external debt. ${ }^{1}$ Given that the domestic banking sector was effectively highly levered it did not require a dramatic decline in project fundamentals to precipitate a crisis. As we show, a significant, albeit temporary, postponement of cash flows is enough to bring down a banking system that has financed itself with short-term debt. There is no doubt, therefore, that a banking system that exhausts its shortterm debt capacity renders itself more prone to crisis. But this capacity may have been exhausted for sound economic reasons - illiquid investments with long-term payoffs were being financed. To see only the adverse effects of the short-term debt without seeing the benefits of long gestation investment such as investment in $\mathrm{R} \& \mathrm{D}$ is to see the risks without recognizing the returns, and can make for distorted policy prescriptions.

This is not to say that the investment being financed always makes economic sense. We will also see a build up in short-term debt when policy distortions result in unsound, rather than simply illiquid, investment. We want to emphasize, however, that the ex ante quality of the investment cannot be readily ascertained from the debris left after a full-fledged financial crisis. One of the consequences of such a crisis is that collateral values collapse because specialized financial skills get taken out of the system (as suggested by Bernanke (1983)). From the 
perspective of the lower realized collateral values, ex ante credit decisions may seem unsound. And considering how much could be realized from the assets if there were no financial crisis, the rush by investors for the exits may seem unwarranted. Yet all these decisions may make perfect economic sense, and may be the best ones given the constraints.

In summary, our argument is that short-term debt mirrors the nature of the investment being financed and the institutional environment that enables investors to enforce repayment. It is no surprise that illiquid or poor quality investment when a bank or banking system is close to its debt capacity will result in a build up of short-term debt. The higher likelihood of crisis stems, not from the short-term debt, but from the illiquidity and potentially low creditworthiness of the investment being financed, as well as the exhaustion of debt capacity. If the investment is considered desirable, the safest way to finance such investment is not to ban short-term debt, but to increase debt capacity by improving governance and transparency so that investors are willing to finance even long gestation illiquid projects with long-term finance.

More generally, before we understand how to respond to banking crises, we must understand what banks really do, and how their capital and institutional structure helps their functioning. This paper develops on work in Diamond and Rajan (1999, 2000a, 2000b). We build a theory of banking that attempts to reconcile the functions a bank performs - primarily of liquidity provision and credit creation - with its peculiar institutional structure - illiquid assets financed by volatile liabilities. We argue that a primary cause of illiquidity in real and financial markets is that specific skills possessed by individuals and institutions typically cannot be packaged together with the assets. Banks, however, can tie their skills to their assets and thus transform otherwise illiquid assets into liquid ones. The way they do this is by financing with extremely volatile short-term liabilities. Paradoxically, the threat of runs caused by trigger-happy creditors allows banks to create and provide liquidity to borrowers and depositors, as well as enhance the flow of credit. The bank's ability to carry out its functions are therefore inseparable

\footnotetext{
${ }^{1}$ Of course, as Shleifer and Vishny (1992) argue, illiquidity can also be endogenous. Even assets with normally high secondary market values can have low liquidation values if there are too many assets
} 
from its potential fragility. In this world, actions that ostensibly make banks more stable -- such as higher capital requirements (i.e., lower short term debt) - could impair their functioning and, paradoxically, end up making them less viable.

We start in this paper with a brief review of our earlier work. We then extend our analysis to a competitive banking system in section I, and examine the kind of loan rates, deposit rates, and capital structures that would emerge in equilibrium in section II. We then analyze the consequences of an unanticipated adverse shock on the banking system in section III. The nature of the shock is particularly important. It is a temporary postponement of revenues for borrowers, similar to that caused by a temporary economic downturn or a temporary adverse shock to terms of trade. It has no consequences on the net present value of anticipated repayments by the borrowers, only on their timing. It turns out that such a shock could have serious adverse consequences for the banking sector in our model, even though we have no sun spots or multiple equilibria. We investigate the effectiveness of various policy responses to the shock. In section IV, apply our model to the recent Asian financial crisis, as well as to the banking crisis in Japan. In section $\mathrm{V}$, we relate our work to the literature and conclude.

\section{Framework}

In what follows, we will first describe the economy, entrepreneurs, investors, and why banks are special in intermediating finance. This section will rely heavily on Diamond and Rajan (1999, 2000a). In the next section, we describe lending and deposit taking, where we will account for competition between banks, which was not the focus of our earlier work.

\subsection{Agents and Projects.}

Consider an economy with entrepreneurs and investors. The economy la sts for two periods and three dates -- date 0 to date 2 . All agents are risk neutral and the discount rate is zero. There are two kinds of goods in the economy - consumption goods and machinery. Each 
entrepreneur has a project idea. The project requires $\$ 1$ of consumption goods at date 0 , which the entrepreneur then converts to machinery. Machinery then produces consumption goods, but since the process of fine-tuning the machinery to produce is complicated, it is uncertain when it will be ready to produce. The project may be completed "early", in which case it will produce consumption goods $\mathrm{C}$ at date 1 or it may be completed "late" and produce $\mathrm{C}$ only at date 2 . Once a machine produces consumption goods, it becomes worthless.

In order to produce consumption goods worth $\mathrm{C}$ at any date, the entrepreneur has to work with the machinery. In other words, production requires his specific human capital skills. While no one knows at date 0 whether a project will be early or late, everyone knows the probability that it will be early is $\alpha$. At date 1, all uncertainty about a project is resolved.

There are two other ways to make use of the machinery. The first is to restructure the project to focus on the near-term production of consumption goods. This can be done at any time until date 1 by the initial entrepreneur himself, and a select few others (we will shortly specify how these can be identified). Restructuring may involve salvaging the consumption goods that have not yet been converted to machinery or abandoning the uncertain technology in favor of tried and tested technologies that can produce goods with certainty. A project, when restructured, produces $c_{1}$ immediately, and $c_{2}$ at date 2 with certainty. Thus a restructured project will produce more goods by date-1 than a project that is known to be late.

A second alternative is to produce with the machinery in a way that is not as dependent on the entrepreneur. This may involve finding an entrepreneur who has similar skills to those possessed by the original entrepreneur, or abandoning some aspects of the original project that were particularly dependent on the original entrepreneur's skills. Let us call this alternative "replacement", even though the range of possible actions may be broader than simply replacing the entrepreneur. What is important is that this involves retaining much of the original strategy so that the timing of cash flows is unchanged. Specifically, when the original entrepreneur is 
replaced, the project produces $\gamma \mathrm{C}$ on the date it would have produced with the original entrepreneur, where $\gamma<1$.

In summary, there are two differences between restructuring the project to squeeze more out of it in the short run and replacing the entrepreneur. First, even though both come at a cost because $c_{1}+c_{2}<1<\gamma C<\mathrm{C}$, replacing the entrepreneur generates more goods in expectation since it preserves the original intent of the investment. Second, restructuring produces some goods immediately if the project is known to be late, while replacement produces none. There is also a similarity. While an entrepreneur can restructure his own project, special skills are needed to find another entrepreneur to restructure the project, or to find a replacement for the entrepreneur while continuing the original project.

We now describe investors, and also who may have the skills to find entrepreneurs to replace or restructure projects.

\subsection{Endowments.}

Entrepreneurs do not have money to finance their projects. There are a large number of investors at date 0 , each with less than one unit of endowment of the consumption good, who can finance entrepreneurs. Investors can potentially finance entrepreneurs directly (our assumptions will rule this out) or finance via banks, an institution that we will describe shortly. The aggregate endowment of investors at date 0 is less than the total number of potential projects, so the economy is short of investment capital. However, because our focus here is not on shortages of liquidity at interim dates, we will assume that fresh investors are born at each date to meet the lower future demand for capital. Intuitively, this framework can be mapped into a developing economy where local seed capital is needed to start projects, but foreign capital will flow in when projects are more mature. 
We assume that all date- 0 investors only value consumption at date 1 . This is an extreme assumption but it limits notational complexity. ${ }^{2}$ The only technology of transforming date 0 consumption goods to date 1 consumption goods is through investment in projects. We could also allow for investors to have access to a costly storage technology, without changing the results qualitatively. We assume, however, that at date 1 investors have access to a storage technology that generates $\$ 1$ at date 2 for every dollar stored at date 1 . This assumption is for plausibility (foreign investors have outside opportunities and are not subject to financial repression) and simplicity (the date-1 discount factor is 1 ).

As in Diamond and Rajan (1999, 2000a), the initial financier of a project has seen the strategy of the project from its early stages and knows how best to find an entrepreneur who can restructure the project or replace the original entrepreneur. Restructuring requires less of the specific expertise of the original entrepreneur, so an entrepreneur who is found by the initial financier can obtain as much by restructuring the project as the initial entrepreneur, i.e., $c_{1}+c_{2}$. But since the original entrepreneur is particularly suited for the originally planned strategy, a replacement who is found by the initial financier obtains only $\gamma C$. Financiers who come in later cannot find anyone to restructure the project or replace the entrepreneur. This is only for simplicity, and our results hold qualitatively if later financiers get something, but not as much as the initial relationship financier.

Since educating the initial relationship financier takes time and effort, we assume that there can be just one such financier for each entrepreneur. We assume that the relationship financier needs constant close contact with the entrepreneur to maintain his advantage so that if he sells the financial claim or it is seized from him, he loses his specific skills next period. This assumption simplifies the analysis but is not necessary. In Diamond-Rajan [1999] we get similar results when the financier retains relationship lending skills no matter what happens to the ownership of the financial claim.

\footnotetext{
${ }^{2}$ This ensures that these investors want repayment at date 1. As in Diamond and Dybvig (1983) or
} 


\subsection{Contracting.}

We consider financial contracts which specify that the entrepreneur owns the machinery and has to make a payment to the financier, failing which the financier will get possession of the machinery and the right to use it as he pleases. So a contract specifies repayments $P_{t}$ the entrepreneur is required to make at date $t$, as well as the assets the financier gets if the entrepreneur defaults. If $\mathrm{P}_{\mathrm{t}}<\infty$, this is a debt contract with promised payment $\mathrm{P}_{\mathrm{t}}$. If $P_{t}=\infty$ this is an equity contract where the outside investor is free to liquidate or replace the entrepreneur (as in Hart-Moore [1994]). Henceforth, we will refer to the financier as the lender.

\subsection{Bargaining with the Entrepreneur.}

Any agent can commit to contributing his human capital to a specific venture only in the spot market. As a result, just before production the entrepreneur may attempt to renegotiate the terms of the loan he agreed to in the past, using the threat of withholding human capital. We assume bargaining at date 2 takes the following form; the entrepreneur offers an alternative payment from the one contracted in the past and commits to contribute his human capital if the offer is accepted. The lender can (1) accept the offer, or (2) reject the offer and replace the entrepreneur immediately (or wait till the next date to do so) (3) reject the offer and restructure the project. The game gives all the bargaining power to the entrepreneur, apart from the lender's ability to exercise control rights over the way the machinery is used in the future (i.e., whether the project is restructured, or the entrepreneur replaced and the control over machinery given to a new entrepreneur). This is for simplicity only, and modified versions of our results hold when there is more equal bargaining power. If the entrepreneur's offer is accepted, the entrepreneur contributes his human capital, and the offered payment is made. The sequence is summarized in full generality in figure 1.

Example 1: Suppose that it is date 1, the project turns out to be early, and at date 0, the entrepreneur promised to pay $\mathrm{P}_{1}=\mathrm{C}$ at date 1 . The entrepreneur knows the relationship lender can 
obtain $\gamma \mathrm{C}$ by replacing him. As a result, he offers to pay only $\gamma \mathrm{C}$ and the lender accepts since he cannot do any better by refusing. Note that lenders other than the relationship lender would have no ability to replace the entrepreneur or restructure the project. As a result, they would not be able to enforce any repayment. The relationship lender's specific skills enable him to collect more, so we will refer to these skills as collection skills.

\subsection{Intermediation.}

With the assumption that one individual's endowment is not enough to fund the project, that at most one lender can acquire collection skills vis a vis a borrower, and that specific skills are necessary for lending to be profitable, investors have no option but to delegate the acquisition of specific collection skills to an intermediary at date 0 . Another (equivalent) motivation for an intermediary is that investors need liquidity at date 1 . In this case (see Diamond and Rajan (1999)), an intermediary provides continuity and reduces the need to sell illiquid assets at firesale prices. Regardless of the motivation for intermediation, it will turn out the intermediary must use demand deposits to commit not to renegotiate with investors. Let us now understand why.

\subsection{Hold up by an intermediary}

Consider an intermediary who has borrowed from other investors, lent initially to the entrepreneur, and now possesses collection skills. In the same way that the entrepreneur can negotiate his repayment obligations down by threatening not to contribute his human capital, the intermediary can threaten to not contribute his collection skills. By virtue of his position in the middle, the intermediary can choose whom to negotiate with first. As in Diamond and Rajan (1999), centrality will be an important source of power for the intermediary. The intermediary will negotiate first with outside investors before concluding any deal with the entrepreneur (else his threat to withhold his collection skills is without bite). So he will open negotiations with investors by offering a different schedule of repayments. The negotiations between an intermediary and investor(s) take much the same form as the negotiations between the entrepreneur and a lender (see Figure 2). The investor can either (1) accept the proposed schedule (2) reject it and bargain directly with the entrepreneur as in figure 1 (this is equivalent to the 
investor seizing the "asset" -- the loan to the entrepreneur -- from the intermediary), or (3) bargain with the intermediary over who will bargain with the entrepreneur. Because of his irreplaceable collection skills, the intermediary will capture a rent from investors (see Diamond and Rajan $(1999,2000 a)$ and will not be able to pass through all it collects from the entrepreneur. In particular, in our example, the intermediary will keep a rent of $\frac{\gamma C}{2}$ from the early project at date 1 (or the late project at date 2), and pass through only $\frac{\gamma C}{2}$ to investors. The prospect of paying this rent to the intermediary can limit the amount the intermediary can raise from investors up front, and limit the entrepreneur's ability to get financing.

Note also that if the project turns out to be late, the value the intermediary can get at date 1 by selling the loan to the project is only $\frac{\gamma C}{2}$. The market value of the loan is so low because anyone buying the loan has to employ the intermediary to collect on their behalf at date 2 , and has to pay him the necessary rents.

\subsection{Depositors as Investors.}

The exception to an intermediary absorbing substantial rents is if the intermediary is a bank financed by demand deposits. The sequential service nature of demand deposits creates a collective action problem that prevents the banker from negotiating depositors down. As a result (see Diamond and Rajan (1999) for a detailed proof), with the appropriate level of outstanding deposits, the bank can commit to pass on whatever it collects to depositors.

To sketch why, we have to first specify the terms of the deposit contract. The deposit contract allows the investor to withdraw at any time. He forms a line with other depositors who decide to withdraw at that time. If the banker does not pay him the full promised nominal repayment $d$, the depositor has the right to seize bank assets (cash + loans) equal in market value (as determined by what the assets would fetch in a sale by the intermediary -- see above) to $d$. Depositors get paid or seize assets based on their place in line. ${ }^{3}$ Therefore if bank assets are

\footnotetext{
${ }^{3}$ An equivalent assumption to depositors seizing loans is that they demand cash and the bank is forced to sell loans at their market value to third parties to meet cash demands. The net effect is the same -- unskilled parties are in possession of the loans after the run.
} 
insufficient to pay all depositors, the first one in line gets paid in full while the last one gets nothing.

Suppose the banker announces that he intends to renegotiate and makes an initial offer. Depositors can (1) accept the new terms, or (2) join a line, with positions allocated randomly, to seize the bank's assets of loans and cash based on what is due to them in the original contract- we call this a run, (3) refuse the offer but negotiate without seizing bank assets. All depositors choose between these alternatives simultaneously. At the end of this stage, either the banker or the depositor will be in possession of the loan to the entrepreneur. If depositors have seized the loan, the banker is disintermediated, and the entrepreneur can directly initiate negotiations with depositors by making an offer. The subsequent steps follow the sequence that we have already documented above, and in figure 1.

There is an essential difference between an intermediary bargaining with investors who have ordinary debt or equity claims on the intermediary, and the bank bargaining with demand depositors. If the bank attempts to renegotiate, or takes any other action that would impair the value of deposits, depositors will choose to run in an attempt to grab a share of the bank's assets to come out whole. As we will argue shortly, the run, by disintermediating the banker, will destroy his rents even though he continues to have specific skills in the short run. Fearing disintermediation, the banker will not attempt to renegotiate and will pass through the entire amount collected from the entrepreneur to depositors. Thus the bank is unlike more conservatively financed intermediaries who will, as we saw earlier, absorb a rent for their collection services.

\section{Example 1 Continued}

How much can the banker commit to pay at date 2 from the loan with face value $\mathrm{P}_{2}=\gamma \mathrm{C}$ ?

Let the banker issue demand deposits at date 1 with face value $d=\gamma \mathrm{C}$ in total, raising the money 
from many depositors. A depositor with claim d is permitted to take cash, or loans with market value, equal to $d^{\prime}$ (or to force this amount of loans to be sold to finance the payment of the deposit). As argued earlier, the market value of the loans at date 1 is only $\gamma \mathrm{C} / 2$ (the amount loan buyers expect to get after paying the banker to collect on their behalf). As a result, not all the depositors will be paid in full if they run. Therefore, if the banker should offer depositors less than $d=\gamma C$, then each depositor has the unilateral incentive to run to the bank to get paid in full, whenever other depositors have not done so first. Therefore, when other depositors have not run on the bank, a given depositor will not make any concessions, preferring to run instead.

Finally, once a run has fully disintermediated the bank's assets, the banker's rents are driven to zero despite his specific skills. To see why, the entrepreneur and depositors (or loan buyers) who now hold the loan to the entrepreneur, can negotiate without the banker intervening. Depositors can threaten to hire the banker to collect the full $\gamma \mathrm{C}$ less the rent they will have to pay the banker for his specific skills. Knowing this, the entrepreneur will offer to pay this net amount directly to the depositors who hold the bank's loans and thus save on the banker's fee. Depositors will accept and the banker will receive zero. Consequently, a bank run drives the banker's rents to zero. Disciplined by the threat of a complete loss in rents, the banker can commit at date 1 to pay the depositors at date 2 the entire amount $\mathrm{P}_{2}=\gamma \mathrm{C}$ extracted from the firm.

\subsection{Financing through a mix of deposits and other claims.}

We have seen that investors holding non-deposit claims are negotiated down by the intermediary giving the intermediary a rent, while depositors are not. What if both kinds of investors simultaneously hold claims on the intermediary? It turns out, as might be expected, that the intermediary can now capture some rent but not as much as when there are no deposits. Let investors (capital) hold a claim which gives them the residual value after deposits $d$ are paid out. Capital can seize the intermediary's assets (cash and loans) if the intermediary does not make an acceptable offer, but it then becomes responsible for paying depositors. In effect, this assumption that capital can always seize assets is tantamount to assuming that capital is outside equity. 
Let the banker threaten not to collect the loan at date 2 . We have already argued that he will be unsuccessful in negotiating depositors down. Hence this threat must be directed at capital.

Example 1 Continued Without the banker, capital will be able to collect nothing from the entrepreneur. So capital will not be able to avoid a run if the banker quits, and will get zero. The net amount available to capital and the banker if the bank does use its skills in collecting the loan is $\gamma \mathrm{C}-\mathrm{d}$. Since neither can get any of the surplus without the other's co-operation, they split the surplus, and each gets $1 / 2(\gamma \mathrm{C}-\mathrm{d})$.

The problem with capital is that it does not provide the banker as hard a budget constraint as demand deposits. As a result, of the amount recovered from the entrepreneur, $1 / 2(\gamma \mathrm{C}-\mathrm{d})$ will be absorbed by the banker as rent. The higher the capital to deposit ratio, the higher the rent the banker gets.

\subsection{Capital Requirement.}

To see what this rent may be, let capital be required to be a fraction $k_{t}$ of the bank's pledgeable assets at date t. Since deposits make up the rest of the bank's liabilities, they will amount to $\left(1-k_{t}\right)$ of the bank's pledgeable assets in value.

\section{Example 1 Continued}

If the only assets the bank has continuing into date 2 are loans to late projects from which it can collect $\gamma \mathrm{C}$, and if the capital requirement is just met, it must be that $k_{2}=\frac{1 / 2(\gamma C-d)}{1 / 2(\gamma C+d)}$ where the numerator on the right hand side is the date- 2 value of capital, and the denominator is the value of capital plus deposits. Therefore, the total amount that can be pledged to investors at date 1 out of the amount the bank collects from borrowers at date 2 is the denominator which, on substituting 
for $\mathrm{d}$, works out to $\frac{\gamma C}{1+k_{2}}$. Since the total amount paid by the entrepreneur is $\gamma \mathrm{C}$, the bank absorbs $\frac{k_{2} \gamma C}{1+k_{2}}$ in rent, an amount increasing in $k_{2}$, and deposits are $\frac{\left(1-k_{2}\right)}{1+k_{2}} \gamma C$.

More generally, only a fraction $1 /\left(1+k_{t}\right)$ of the total date-t value of the bank can be pledged to outsiders at date $\mathrm{t}-1$. The banker absorbs the remaining amount as rent.

Why might the banker issue capital instead of deposits? The problem is that deposits are a very rigid form of financing. This is good in that it disciplines the banker and enables him to commit to pay out. It is bad if there is any uncertainty in bank asset values because a drop in bank asset values will precipitate a run, disintermediating the banker, and further reducing their value. Capital can act as a buffer in such cases because, unlike deposits, its value adjusts to underlying asset values. Specifically, when there is uncertainty, Diamond and Rajan (2000a) show that the optimal capital structure for the bank may involve some capital in addition to demand deposits. In the rest of the paper, we will assume there is a capital requirement of $k_{t}$ for banks, either specified by regulatory authorities or endogenously chosen as a result of the un-modeled uncertainty about asset values.

\subsection{Competition among banks.}

We assume that there are a large number of banks in this economy. Since there is a capital shortage in the economy at date 0 , we normalize the total amount that each bank can raise at date 0 at the competitive rate, to $\$ 1$. Each bank has a large number of loans so that it is fully diversified across borrower types. So fraction $\alpha$ of a bank's loans will turn out to be to early projects and fraction (1- $\alpha)$ to be late projects. Let us now determine how much each bank charges entrepreneurs and how much it pays depositors.

\section{Loan and deposit rates.}


Since there is a capital shortage in the economy at date 0 , banks will charge entrepreneurs the maximum for a loan, and offer investors the maximum value consistent with the constraints on pledgeability imposed by the capital requirement. Also, since all initial investors will want to consume at date 1 , the bank should be able to raise enough at date 1 to pay them back what was promised earlier, modulo any date-1 renegotiation.

Let us first determine how much a bank can make by lending, then what it will promise to pay investors given its revenues from lending.

\subsection{Lending.}

The bank will charge the maximum possible on each loan it makes. Entrepreneurs can pledge to pay, at maximum, $\gamma \mathrm{C}$ when they produce. So at date 0 , the bank will ask entrepreneurs to pay $\mathrm{P}_{1}=\gamma \mathrm{C}$. The entrepreneurs with early projects will repay the bank at date 1 , while entrepreneurs with late projects will default and have to renegotiate their debt. The bank will then have the maximum leeway to decide how to deal with the late project - whether to restructure, or preserve long run value by keeping the project as a going concern.

\subsubsection{Response to a default.}

In order to repay all date-0 investors, the bank has available the inflow from repayments by early entrepreneurs, the amount it can raise against the loans to the late projects it keeps as going concerns, and the amount it can raise by restructuring late projects. Let us examine each of these. As indicated earlier, there is no aggregate shortage of consumption goods at date 1 and storage is in use so the prevailing interest rate between date 1 and date 2 is 1 .

The $\alpha$ early entrepreneurs will repay $\gamma \mathrm{C}$ to the bank. The bank can also sell the late project for $c_{1}+c_{2}$ to a suitable, cash rich, early entrepreneur. Note that this is more than the 
original entrepreneur can pay to retain his late project, since he can generate, at most, $c_{1}$, and he has no additional funds to pay with. ${ }^{4}$

An alternative for the bank to selling late projects to the cash rich is to retain the projects as going concerns and borrow to finance them. The banker expects to collect $\gamma \mathrm{C}$ at date 2 from the initial entrepreneur if the banker keeps the project as a going concern (that is, if the banker forgives the default and reschedules the date-1 payment to date 2). He can raise $\frac{\gamma C}{\left(1+k_{2}\right)}$ in deposits and capital at date 1 against the prospective payment at date 2 , given the capital requirement and the prevailing deposit rate.

The banker and the entrepreneur with the late project prefer borrowing against the late project to it being sold and restructured, the former because he can extract rents of $\frac{k_{2} \gamma C}{1+k_{2}}$ for his specific collection skills at date 2 , the latter because he collects rents at date 2 of $(\mathrm{C}-\gamma \mathrm{C})$ for his specific skills in running the project. The problem becomes interesting when

$$
\frac{\gamma C}{1+k_{2}}<c_{1}+c_{2}<\gamma C
$$

so that the amount the bank can raise at date 1 against a rescheduled loan is less than the amount that can be obtained by restructuring the project, which in turn is less than the amount the bank recovers from the borrower if the loan is held to maturity. Inequalities (1.1) imply a conflict of interest between the banker and the bank's investors. The banker may be forced to restructure the loan to repay investors at date 1 even though the banker (like the entrepreneur) is personally better off rescheduling it. Since restructuring loans is an intimate part of a banker's job, and very hard for investors to supervise (see Myers and Rajan (1998)), we will assume that the banker has

\footnotetext{
${ }^{4}$ The cash flow at date 2 cannot be pledged since outsiders have no way to extract it. So the cash rich early entrepreneur can pay more for a late project than can the entrepreneur who originated it.
} 
the freedom to choose the fraction $\mu$ of loans sold at date 1 for restructuring. Then the total amount, $\mathrm{V}(\mu)$, the bank has in hand at date 1 to pay investors is

$$
V(\mu)=\alpha \gamma C+\mu(1-\alpha)\left(c_{1}+c_{2}\right)+(1-\mu)(1-\alpha) \frac{\gamma C}{1+k_{2}}
$$

The first term is the repayment from early projects, the second term is the amount received from sales of late projects for restructuring, the third term is the amount raised against loans to late projects that are rescheduled to be repaid at date $2 . \mathrm{V}(\mu)$ is clearly increasing in $\mu$. However, the banker prefers to set $\mu$ at the lowest level possible that also allows him to repay investors. ${ }^{5}$ Let us now determine what this is, as also the level of deposits issued at date 0 .

\subsubsection{Level of deposits issued by the bank at date 0}

$\mathrm{V}(\mu)$ is the pledgeable value of the bank at date 1 . Therefore, given the capital

requirement, the level of deposits issued at date $0, \mathrm{~d}_{0}$, cannot be greater than $\frac{\left(1-k_{1}\right)}{\left(1+k_{1}\right)} V(\mu)$.

Since the banker can pay investors the maximum possible by issuing the greatest amount of deposits, and since competition and the date- 0 capital shortage will force the banks to pay the maximum, banks will issue the maximum amount of deposits.

At date 1, capital and the banker will bargain about how much the latter has to pay the former. Following earlier arguments, capital will get half the excess over deposits when assets are put to their best use (from capital's point of view). Since assets have their maximum value to

\footnotetext{
${ }^{5}$ There is the subtle issue of whether the banker would like to sacrifice his date-1 rents in order to preserve date- 2 rents. In other words, by reducing $\mu$, the banker is also reducing his date 1 rents (since he shares the excess of date-1 funds over deposits equally with capital). The maximum cost in terms of date 1 rents per loan rescheduled instead of sold is $c_{1}+c_{2}-\frac{\gamma C}{\left(1+k_{2}\right)}$. The maximum benefit is the date- 2 rent,
} 
capital when all late loans are restructured $(\mu=1)$, the total payout, which is the value of capital plus deposits is

$$
1 / 2\left(V(1)-d_{0}\right)+d_{0}=1 / 2\left(V(1)+d_{0}\right)=1 / 2\left[V(1)+\frac{\left(1-k_{1}\right)}{\left(1+k_{1}\right)} V(\mu)\right]
$$

So for the banker to be able to pay investors at date 1 , he must choose a $\mu$ such that

$$
V(\mu) \geq 1 / 2\left[V(1)+\frac{\left(1-k_{1}\right)}{\left(1+k_{1}\right)} V(\mu)\right]=>V(\mu) \geq \frac{\left(1+k_{1}\right)}{\left(1+3 k_{1}\right)} V(1)
$$

This inequality then determines the equilibrium value of $\mu$, the amount of loan restructuring the bank will be forced to do. If even $V(0) \geq \frac{\left(1+k_{1}\right)}{\left(1+3 k_{1}\right)} V(1)$ then the banker will not restructure any loans and $\mu=0$. Otherwise, there will be a unique non-zero le vel of $\mu$ that solves (1.4) as an equality. Some simple algebra shows

Lemma 1: The equilibrium level of loans the banker restructures, $\mu$, decreases in the initial capital requirement, $\mathrm{k}_{1}$.

Intuitively, the greater the capital requirement, the greater the banker's leeway to take his preferred action, protected by his cushion of rents. Since he prefers to continue projects rather restructure them, a greater capital requirement in effect gives him a longer horizon. More late projects are funded into the long term.

The bank's investors are, however, hurt in two ways. First, the fraction of the future bank value the bank can pledge falls in $k_{1}$. By limiting the bank's ability to pay out, a higher $\mathrm{k}_{1}$ increases the bank's rents even in this competitive world. Second, and as a consequence of the

\footnotetext{
$\frac{k_{2} \gamma C}{\left(1+k_{2}\right)}$. Therefore the banker prefers to reduce $\mu$ if the latter is greater than the former, i.e., on
} 
first effect, the banker's freedom to take the self-interested action (of continuing rather than restructuring late projects) also increases, again to the detriment of the investor. So we have

Lemma 2: The amount the banker can pledge to investors at date $0, \frac{V(\mu)}{\left(1+k_{1}\right)}$, falls in the capital requirement, $\mathrm{k}_{1}$.

The point is that a higher capital requirement acts like an interest rate ceiling, hurting investors and benefiting banks and the industrial sector. Of course, if investors have alternative ways of investing their funds -- which we have assumed away so far -- a high capital requirement will eventually make it impossible for banks to pay investors their opportunity return, and the size of the banking sector will shrink.

There is also a more direct effect of a high capital requirement. By limiting the extent to which banks lever up through demandable deposits, they limit the extent to which competition renders banks fragile and susceptible to future adverse shocks.

In summary, a higher capital requirement has a number of effects. A high date-1 capital requirement limits pledgeability at date 0 , and helps contain inter-bank competition. Ex-ante, this also gives banks a greater cushion to weather adversity. But a high date-2 capital requirement also inhibits the bank's ability to pledge future receipts at date 1, making it more susceptible to adverse shocks at date 1.

Given the importance of the capital requirement, it is useful to reconsider where it comes from. We can think of the capital requirement in our model as explicitly required by the authorities, partly to maintain the stability of banks. But there are other interpretations. As Diamond and Rajan (2000) argue, even if a bank is interested in maximizing the amount it can pledge (which is what competition forces banks to do in this model) it may be optimal for a bank

simplifying, if $c_{1}+c_{2}<\gamma C$ which is true. 
to finance itself with some capital when faced with uncertainty. This is because capital acts as a buffer and saves on the cost of bank distress. The higher the expected costs of distress, the greater the value of capital, even though it comes at the expense of greater bank rents. Thus we could think of the capital requirement as the endogenously chosen optimal level of capital that allows the bank to raise the maximum possible, taking into account the uncertainty about future states. If the expected future costs of bank distress increase, the capital requirement imposed naturally by the market can be quite high, making more probable current financial distress as the bank finds itself unable to pledge future value.

\section{An adverse shock.}

Given an anticipated $\alpha^{0}$ and an implied $\mu^{0}$, banks will choose a commensurate capital structure at date 0 . Now let us see what happens when an unexpected adverse event occurs: i.e., when $\alpha$ falls to $\alpha^{\mathrm{L}}$ immediately after date $0{ }^{6}$ Note that at the prevailing interest rates, the present value of the amounts collectible by the bank is not changed. All that has changed is that the effective maturity of the projects -- the payback period - has lengthened. Such a shock could be caused by a temporary economic downturn or a temporary adverse shock to terms of trade to the export sector. Recent empirical work (Kaminsky and Reinhart (1999), Demirguc-Kunt and Detragiache (1999)) indicates that such shocks do predict banking crises.

\subsection{Effect of adverse shock on restructuring.}

After the shock the bank will have to pay out a sum

$$
1 / 2 \max \left[\alpha^{L} \gamma C+\left(1-\alpha^{L}\right)\left(c_{1}+c_{2}\right)-d^{0}, 0\right]+d^{0}
$$

\footnotetext{
6 We assume this event occurs with an infinitesimal ex-ante probability. The optimal initial bank structure is nearly identical if instead there is a small ex-ante probability of the shock.
} 
The first term is the payment to capital at the new level of $\alpha$, the second is the payment to depositors that was fixed at date 0 . Note that while payments to capital adjust to the adverse shock, deposits do not. It is in this sense that capital is a buffer.

The bank can raise

$$
\alpha^{L} \gamma C+\mu^{L}\left(1-\alpha^{L}\right)\left(c_{1}+c_{2}\right)+\left(1-\mu^{L}\right)\left(1-\alpha^{L}\right) \frac{\gamma C}{1+k_{2}}
$$

to pay investors at date 1 . The bank will survive if there is a $\mu^{\mathrm{L}}$ less than or equal to 1 , such that (1.6) $\geq(1.5)$. It is straightforward to show that the lower the $\alpha^{\mathrm{L}}$, the higher will have to be $\mu^{\mathrm{L}}-$ the amount of restructuring -- for the bank to meet its obligations. Put differently, as the effective maturity of the projects lengthens, the bank's horizons will shorten. The reason for this seemingly perverse outcome is simple. Given its liability structure, the bank needs the repayment from early projects to be able to continue late ones. But a lengthening of maturities reduces the early repayment, and the bank's flexibility, precisely when it is most needed!

If

$$
\alpha^{L} \gamma C+\left(1-\alpha^{L}\right)\left(c_{1}+c_{2}\right)<d^{0}
$$

$\alpha$ will have fallen so low that even by setting $\mu^{\mathrm{L}}=1$, the bank cannot repay depositors. The bank will be insolvent. Anticipating this, depositors will run on it. Let us now examine what happens as a result of a run.

\subsection{Bank run}

An extremely low realization of $\alpha$ will trigger off a run as depositors understand there is not enough value to repay all of them. Note that the run will take place as soon as $\alpha$ is realized, 
which will be before date 1 . As a result, the bank will not have an opportunity to collect from early projects either.

At the end of the run, depositors will have seized the loans. Since the run takes place before date 1 , no entrepreneur has the money to pay depositors without restructuring. If the entrepreneur restructures the project, he can commit to pay up to $c_{1}$ immediately. Depositors can also negotiate with the banker about collecting from the entrepreneur. The banker cannot wait till future dates to act since his specific skills will disappear by that time. So the only way for the banker to use his specific skills at the time of the run is to sell the project to an appropriate buyer for restructuring. ${ }^{7}$ Of course, since deposits no longer discipline the banker, the depositor will expect to get only half of what the banker collects, since the banker will extract his rent. So depositors expect $1 / 2\left(c_{1}+c_{2}\right)$ from hiring the banker to negotiate on their behalf. If $c_{1} \geq 1 / 2\left(c_{1}+c_{2}\right)$, which seems plausible given the nature of restructuring, the entrepreneur will restructure his project and pay depositors $1 / 2\left(c_{1}+c_{2}\right)$ directly in return for their giving up all future claims on him. The entrepreneur will retain $1 / 2\left(c_{1}+c_{2}\right)$. The banker will get zero.

The run, however, forces all projects, including the early ones, to be restructured, causing a net loss of value to the economy. If $(1-\gamma) C>1 / 2\left(c_{1}+c_{2}\right)$ entrepreneurs are also worse off as a result of a run, even though they end up repaying less on their loan. But because the bank is set up so that depositors cannot be negotiated down prior to a run, a run is an inevitable consequence unless there is outside intervention.

To summarize, the run is caused by the rigidity of deposits. The higher the anticipated $\alpha^{0}$, the higher the equilibrium level of deposits $d^{0}$, and the higher the threshold $\alpha_{L}$ that sets off a run. We have the following proposition:

\footnotetext{
${ }^{7}$ Alternatively, if the banker will maintain his relationship long enough to collect from the entrepreneur at date 1 , hiring the banker yields $\gamma \mathrm{C} / 2$, and if $\mathrm{c}_{1}>\gamma \mathrm{C} / 2$ the entrepreneur will pay $\gamma \mathrm{C} / 2$ rather than $\mathrm{c}_{1} / 2$. This case is sufficiently similar that we do not analyze it further.
} 


\section{Proposition 1:}

(i) For any anticipated $\alpha^{0}$, the extent of restructuring decreases in the level of $\alpha_{L}$.

(ii) For any unanticipated $\alpha_{\mathrm{L}}$, the extent of restructuring increases in the anticipated $\alpha^{0}$.

Example: Let $\mathrm{C}=2, \alpha^{0}=1, \mathrm{c}_{1}=0.55, \mathrm{c}_{2}=0.3, \gamma=0.525, \mathrm{k}_{1}=0.05, \mathrm{k}_{2}=0.3$.

Anticipating all projects will be early, the bank knows it can collect $\gamma \mathrm{C}=1.05$ at date 1 . Therefore, given the capital requirement, it will issue 0.95 of deposits at date 0 , and capital will anticipate a payment of 0.05. But if a project is delayed, the bank can raise only $\frac{\gamma C}{1+k_{2}}=0.81$ against it. By contrast, it can get 0.85 by restructuring the project. It is easily seen that if $\alpha^{\mathrm{L}} \geq 0.58$, no project need be restructured since the bank will get enough from early projects and can raise enough against late projects to repay all deposits. If $0.5 \leq \alpha^{\mathrm{L}}<0.58$, some projects will be restructured. If $\alpha^{\mathrm{L}}<0.5$, the bank cannot pay depositors even after restructuring all late projects, and will be run. Note that a delay in payment, with no change in present value, is enough to precipitate the run.

\subsection{Outside Intervention.}

After an adverse shock, either only the number of restructured projects will increase or, in addition, a run will occur and all projects must be restructured. In the latter case, holders of claims on the bank take larger losses than just the loss from restructuring. Value also disappears because they can no longer rely on the bank to collect on their behalf.

What policies could a government or international agency implement to prevent a crisis? It is important to stress that there is no shortage of potential investors at date 1 and thus no aggregate shortage of liquidity. For example, even if plenty of foreign investors are willing to provide capital at a normal rate of return, the bank cannot raise enough to pay off existing deposits without restructuring or, in the case of a run, cannot commit to give outside investors 
sufficient future returns even if all late projects are restructured. As a result, unsubsidized lending to the banks will not prevent the crisis. If a loan from the regulators or international agencies could get a normal rate of return, then any loan from private agents could secure that return. Thus the traditional provision of liquidity through loans to the banks, or the purchase of securities by individuals or banks, has no effect. This is not a liquidity crisis in the traditional Lombard Street sense (see Diamond and Rajan (2000b) for a model of a liquidity crisis), although it is the borrowers' lack of liquidity that causes a bank solvency crisis.

\subsubsection{Subsidies.}

In order to prevent restructuring or runs, banks must be provided subsidized loans after the shock. The bank needs a subsidy of $d^{0}-\alpha^{L} \gamma C-(1-\alpha) \frac{\gamma C}{1+k_{2}}$ if it is to completely avoid restructuring, and a smaller subsidy of $d^{0}-\alpha^{L} \gamma C-\left(1-\alpha^{L}\right)\left(c_{1}+c_{2}\right)$ if it is to avoid a run. Of course, the subsidy is greatest if the government lends against the full value of each late loan. A bank can then survive and also avoid restructuring even if all loans turn out to be late. Thus a

loan of $\left(1-\alpha_{L}\right) \gamma C$ is really a subsidy of $\left(1-\alpha_{L}\right) \frac{k_{2} \gamma C}{1+k_{2}}$. The bank survives, not because of the loan but because of the subsidy (presumably recovered by taxation).

\subsubsection{Capital infusion}

When borrower illiquidity causes a bank solvency crisis, an equivalent government intervention to subsidized lending is to provide capital to the bank. Again, recapitalization involves a subsidy of the same magnitude as the one above, otherwise private investors would have provided the capital.

\subsubsection{Changing Capital Requirements}

Lowering capital requirements in the future would appear to be a method of allowing the bank to survive. However, when the bank's loan portfolio is risky, regulatory capital 
requirements may not be what limit the bank's ability to commit to make large payments to investors. As discussed earlier and in Diamond and Rajan (2000a), the market may impose a capital requirement over and above that imposed by regulators. In such a case, even if regulatory capital requirements were eliminated, banks would not be able to commit to pay outsiders the full future value they collect from relationship-based loans. Ex-post reductions in capital requirements will do little to allow banks to commit higher returns to outside investors. The problem may be that deposits are too high, not that the banker gets too much rent.

The run resulting from the shock to borrower liquidity occurs due to the rigidity imposed by a high level of deposits. An alternative ex-ante policy would be to require a higher level of capital at date 0 , and thus fewer deposits (i.e., lower short term debt). This policy of increasing $\mathrm{k}_{1}$ might work if those who invest in the banks have limited alternative investment opportunities. Higher capital requirements reduce the return that can be provided to investors (see lemma 2). For the bank to survive the unanticipated shock, the bank would need to have $\mathrm{k}_{1}$ such that $\alpha^{L} \gamma C+\left(1-\alpha^{L}\right)\left(c_{1}+c_{2}\right)=d^{0}=\frac{\left(1-k_{1}\right)}{1+k_{1}} V(\mu)$. This would limit the bank's ability to fund itself at all at date 0 . For example, if $\alpha_{L}=0$, the bank can promise initial depositors only $c_{1}+c_{2}$. If investors have alternative investment opportunities, the capital requirement will not allow the bank to raise sufficient finance to begin with. Very high capital requirements will prevent banking panics by preventing banking itself.

Deposit insurance has similar effects to an ex ante capital requirement when fairly priced, and is similar to a subsidized recapitalization when underpriced. But if the deposit insurer requires prompt corrective action to enforce a minimum level of capital (and sticks by this threat to close the bank unless it raises sufficient capital), and the deposit insurer and the remainder of the government are prohibited from providing subsidized capital to the bank, the bank is under the same incentives as the threat of a run. 
More generally, there is an analogy between a higher capital requirement and a Chile an style tax on short-term capital outflows. Both lead to longer term financing but are not costless. When short term debt provides needed commitment, the extra stability from a longer term capital structure is only available at the cost of paying higher rates to investors or at the expense of some credit rationing.

\subsubsection{Suspension of Convertibility}

Because depositors rush to withdraw to avoid losses incurred by those at the end of the line, an obvious way to stop the bank run is to suspend the right to withdraw on demand. If the result of the suspension is that the deposit claims are renegotiated, effectively converting deposits to equity, then the run will indeed be stopped. The bank will appropriate all of the rents associated with being an all-capital bank and deposits will provide no disciplinary effect.

Suspension is similar to a subsidized recapitalization of the bank, the difference being that the existing depositors rather than the tax-paying public are the source of subsidy. The problem with suspension is that it removes the commitment value of deposits. As with an ex-ante increase in capital requirements, the bank that has the freedom to suspend when a run is imminent may not be able to raise sufficient funds to make loans.

Alternatively, if outside parties like regulators or some industry group were to enforce suspension only when the bank cannot raise the full value promised to depositors (rather than when it simply wants to renegotiate, see below), then we get something similar to a government subsidized recapitalization. Effectively, deposits become state contingent. In situations where a run would otherwise occur, the cost averaged across depositors of such a suspension is zero or negative (it is negative when they get $\frac{\gamma C}{2}$ rather than $\frac{c_{1}+c_{2}}{2}$ ).

However, it is hard to see how an outside party can distinguish between situations where asset values are intrinsically low and ones where asset values are low because the banker is 
extracting rents through higher salaries, perk consumption, inefficiency, or plain corrupt lending practices (these are analogues of what we mean by the rents extracted from bargaining). Historically, suspension was allowed only when a system wide bank meltdown was imminent and not when individual banks got into trouble. This does not eliminate the exercise of judgement, nor does it eliminate group moral hazard. Ultimately, the case for ex-post bailout, no matter who pays for it, must be that the short run benefit to the economy exceeds the long run loss of commitment value.

\section{What does the model have to say about recent crises?}

\subsection{East Asia}

There are many theories of what caused the East Asian crisis in 1997-1998. Potential culprits include panic stricken foreign investors (Radelet and Sachs (1998)), hedge fund managers out to wreck the upstart Asian economies (Mahathir Mohammed in various speeches), corrupt corporate governance practices (Krugman (1998), Johnson, et al. (1999), Pomerleano (1998)), bank moral hazard (Dooley and Shin (1999)), and inadequate financial infrastructure (Rajan and Zingales (1998)). But any reasonable theory should explain four features of the crisis, three of them well known, and one less well known.

\subsubsection{Four features of the crisis.}

First, prior to the crisis, foreign lending to each of these countries was increasingly short term and largely intermediated by domestic banks. In fact, foreign banks lent to domestic banks in preference to lending to domestic firms (the exception is Indonesia, where a substantial portion of foreign lending was direct). Second, there seemed no obvious shock to fundamentals prior to the crisis. This has led some (see Chang and Velasco (1999) or Radelet and Sachs (1998)) to argue that the crisis was a result of panics or tipping in a model of multiple equilibria. Third, the crisis spread quickly to other countries in South East Asia, but had little effects on countries in Latin America. Finally, and this is a feature that is less well known, not all foreign lenders curtailed their lending in these countries. In fact, lending by foreign banks with domestic 
operations increased in many countries soon after the onset of the crisis, both in absolute terms and as a fraction of total loans.

\subsubsection{Can our model explain these four features?}

While we do not have a full fledged model of an open economy with a fixed exchange rate, our model throws some light on the roots and the consequences of the crisis, consistent with the four features described above. First, in economies where corporate governance is in its infancy, and bankruptcy laws are virtually non-existent, the specific expertise of domestic institutions like banks, that know how to exercise power over borrowers even when explicit protections are inadequate, is necessary for loans to be made (see Rajan and Zingales (1998)). It is no wonder that much of the financing to firms from foreign investors (including foreign banks), who wanted to diversify internationally, had to be channeled through domestic banks. Moreover, in order to keep rents at the domestic banks at minimal levels, foreign investors had to hold demandable claims. ${ }^{8}$

There are many candidates for the trigger in the first country that succumbed, Thailand. One culprit that fits our model is slowing earnings in the export sector because of an appreciating exchange rate. While the rate could correct itself in the longer run, in the short run it would imply illiquid borrowers among the exporters. As our model suggests, a delay in payments by borrowers could be enough to create a solvency problem for their banks, especially if the endogenous capital requirement were high. The problem would have been especially acute if prior to the crisis domestic banks had become highly levered because the crisis was not anticipated. As Radelet and Sachs (1998) argue after examining bond yields and sovereign bond ratings, there is little evidence that the crisis was anticipated.

Once the solvency problem was evident bank runs would have become inevitable. The difference between the value of loans when domestic bankers have collection skills, and their 
value in a post-bank arm's length world, with inadequate bankruptcy laws and poor disclosure rules, would have been substantial. The low post meltdown value of the bank's assets could easily be confused as evidence of "crony capitalism" while, in fact, ex ante these may have been sound relationship based loans.

As domestic banks shrank, or were placed in suspended animation, there would have been few avenues through which foreign investors could lend without fear of being dispossessed. The short term liabilities of the banking system served as a commitment that local collection skills would be used on behalf of foreigners, but with the banking system defunct, foreign investors would be thrown at the mercy of the country's inadequate laws and rules. Local borrowers would no longer be credit worthy. Therefore, the worst hit countries would have been those with inadequate bankruptcy laws, investor protection statutes, and disclosure rules, not because these were the ones with the worst "crony capitalism" as some have suggested (see, for example, Johnson, et al. (1999)) but because these were the ones that could least survive the demise of their financial institutions.

Thus far, we have suggested why the build up of borrowing was necessarily short term, and why the collapse was so severe despite there being no obvious long term adverse shock to fundamentals. Consider now contagion. The contagion across countries could be a result of trade links that cause a liquidity problem for borrowers in one country to result in delayed payments to suppliers from a trading partner, causing a lengthening of maturity of payments in that country also. As Glick and Rose (1998) show, countries with important trade links to a country that first experiences a crisis are more likely to experience a crisis themselves. So surrounding countries not only directly experienced the adverse shocks that Thailand did, but also indirectly experienced a delay in pay-back as Thai customers and Thai banks delayed payments. As a result, they also caught the bug.

\footnotetext{
${ }^{8}$ There is the question of why these claims had to be denominated in foreign currency, as they were in many countries. One explanation is that foreign currency claims are "harder" because they cannot be devalued away by a government sympathetic to the banks.
} 
Our model's explanation - that deliberately fragile financial institutions melted down in the face of a largely unanticipated shock, leading to the disappearance of specific lending skills and a sustained period of credit shortage in the economy -- should be contrasted with models emphasizing aggregate liquidity shortages or panics as the reason for melt down. As we discuss below in section 5, because these models do not involve banks with specific collection abilities, once the run is over, foreign lenders could provide any needed liquidity and re-float the entire system. That the crisis persisted until the banking system was recapitalized suggests something more was going on.

The notion that all foreign investors fled in panic does not sit well with the fact that there wasn't a substantial decline in loans made by domestic operations of foreign banks. Instead, there was an increase (see figure 3). Our model would suggest foreign investors without local lending expertise fled as soon as they perceived the domestic banking system was insolvent and unable to intermediate on their behalf. However, foreign banks with domestic operations had local lending experience, and were diversified across many countries so that they could survive any lengthening of borrower maturities. As a result, the crisis uncovered a whole new set of lending opportunities for them, and their lending increased. In addition, this suggests that the costs of the run were through the financial system and not directly a destruction of real opportunities. If the real economy was the destroyed by the run (or by its cause), the lending opportunities of foreign bank branches should have been eliminated as well.

Finally, foreign banks with domestic operations were unlikely to benefit from a government bailout. Even these banks did not curtail their lending prior to the crisis. This suggests that domestic lending may not have been solely motivated by moral hazard, a desire to take advantage of implicit deposit insurance. Rather, there was some belief that it was indeed profitable.

\subsubsection{Policy responses.}

If a policy goal was to ensure the continued flow of credit to firms, the rapid closure of failing banks was the wrong response. Recapitalization on a large scale preserved the banking 
system, but may have been unprofitable, and may have had long term effects due to an anticipation of future bailouts. Nevertheless, a selective recapitalization may have been the only way in the short run to protect the economy from long term adverse effects.

From a long term perspective, the best way to reduce the sensitivity of the economy to the health of the banking system is to improve disclosure rules, investor protection statutes, and bankruptcy laws, thus reducing the importance of relationship lending (also see Rajan and Zingales (1998)) and the need for fragile capital structures. Chilean style taxes on withdrawals, or the mandatory lengthening of the maturity of foreign borrowing, like increased capital requirements, simply attack the symptom of the problem rather than its fundamental cause. They can increase stability ex ante, at the cost of reducing access to capital ex ante, and diminishing the flexibility to survive crises ex post. In fact, when confronted with incipient capital outflows in 1997-98, Chile did away with its restrictions. In conclusion, if the Asian economies do not reform and continue to need the specific collection skills of banks, the banks will continue to have a fragile capital structure to attract foreign investors.

\subsection{Japan}

The long recession in Japan reduced the value of loans to firms in Japan, and reduced the value of bank loan portfolios. The level of capital was reduced to a low or negative number, but the banks were not closed. Recently, the government has started to require banks to write off loans and bring accounting capital in line with economic capital. This, combined with the internationally imposed Basel capital requirements, has left banks in the position similar to a bank nearly threatened by a run. As a result, undercapitalized banks squeeze their borrowers and do not make new loans. Some viable borrowers are forced to restructure and some banks are being closed. Undercapitalized banks have incentive to break valuable lending relationships with viable borrowers. If lending relationships are still deemed valuable in Japan, recapitalization (or its equivalent) is the only way to allow those relationships to be maintained. Diamond (1999) provides a detailed analysis on how to determine the appropriate amount of capital to provide, and which banks to recapitalize. 


\section{Relationship to literature}

It is useful to see how our model differs from the literature, especially in relating to crises.

\subsection{Diamond and Dybvig}

In the simple version of Diamond Dybvig [1983] with no aggregate uncertainty, a run can be caused by self-fulfilling beliefs that depositors will not lend at date 1. Applied to the Asian crisis, this would mean foreigners panicked believing other foreigners would not continue to lend (see, for example, Radelet and Sachs (1998)). If local businesses have too little liquidity (foreign currency reserves) to replace the foreign deposits, then there is a run equilibrium caused by the fear of a future run. A way to stop such a run is suspension of convertibility (capital controls). If it is just the fear of a run that causes problems, then suspension that persists until depositors calm down should stop the run. Moreover, since the Diamond-Dybvig model aggregates the loan market together with the corporate sector, and does not ask why loans are illiquid, the losses from a run then are the physical losses from liquidation of capital. If one interprets the model as denying a special role for bank monitoring or loan collection, then it implies that anything that stops the liquidation, even if it destroys the banks, will avoid the losses.

By contrast, our view is that the physical liquidation is only part of the loss. The lost relationship capital and financial capacity (ability to commit to pay) of the banks is at least as important. Whether the cause of the Asian crisis is a pure panic or a shock to borrower liquidity that causes bank insolvency, our framework suggests that the loss of financial structure is a major cost of letting the crisis destroy the financial system (see also Bernanke (1983)).

Another approach is based on the aggregate uncertainty version of the Diamond-Dybvig model. If all potential depositors need liquidity, and there is too little of it to go around, loans must be liquidated at a loss, and a run can occur. This does not seem to fit the facts about East Asia. Banks in East Asia had access to worldwide liquidity at the beginning of the period, and would have retained it if foreign holders had found it profitable to lend. In many countries, the 
banking crisis did not abate even when domestic authorities or international lending organizations agreed to pump liquidity into the system. For example, in Korea, roll over interest rates on shortterm domestic bank debt did not decline when the IMF injected over $\$ 10$ billion in liquidity and back up lines were made available from other sources. It took a government guaranteed restructuring of deposits for the outflows from banks to cease (see Lane et al. (1999)). Either the limit to solvency based on borrower liquidity problems that we have described, or a panic of the Diamond-Dybvig variety among foreign investors seem to provide a better insight into the problems in East Asia. ${ }^{9}$

\subsection{Inside capital as a bonding device.}

Capital in our model works to buffer the rigidity of deposits and protects the bank against uncertainty. However, the bulk of the incentive effects are provided by short-term liabilities like deposits, which provide the necessary stick if the banker misbehaves. Outside bank capital or longer maturity claims reduce the weight of the stick, though they do create rents for the banker, giving him a long-term stake in the bank.

Our view that bank capital structure can be used to commit should be contrasted with models that stress the importance of the personal wealth of entrepreneurs and bank owners in ensuring their smooth, agency-free, functioning. Inside capital or wealth contributed by managers is important when there are binding incentive constraints on what fraction of returns can be pledged to outsiders, as in Bernanke-Gertler [1987], Diamond [1991], and (for banks) Holmstrom-Tirole [1997, 1999]. In such a case, entrepreneurs and bankers must have sufficient personal wealth to allow marginal project to attract or retain finance. If the wealth of entrepreneurs or bankers falls, due to lower profits of firms, then lenders will liquidate because

\footnotetext{
${ }^{9}$ Smith (1991) discusses how this notion of an increased aggregate demand for liquidity is consistent with many important historical crises, but these have a different character than the one in East Asia. We discuss the role of changes in the excess supply or demand of aggregate liquidity in the context of our framework in Diamond-Rajan (2000b).
} 
firms are worth more dead than alive (net of the return that must go to entrepreneurs and bankers). Renegotiation will not help because closing banks and firms is in the ex-post interest of lenders. Neither will recapitalizing banks with outside capital since this does little to bond the actions of the banker.

By contrast, in our model, it is the necessary rigidity of bank deposits that is responsible for the financial crisis. Absent intervention, ex-post-inefficient outcomes can take place. This makes all the difference in policy evaluation, because our approach implies that one must be cautious about using the bad realized outcome to argue that the original capital structures were too fragile.

\section{Conclusion}

Financial crises are caused by the rigidity and fragility of the institutions at the center of these crises, banks. It seems obvious that the way to avoid future crises is to make these institutions stable. Yet it may be impossible for banks to carry out their essential functions and be stable at the same time. Perhaps the only way for regulators to make a financial system completely stable is to do away with the need for the functions banks perform. Few economies are at that advanced stage of financial development.

\section{References}

Bernanke, Benjamin, 1983, Non-monetary effects of the financial crisis in the propagation of the great depression, American Economic Review 73, 257-276.

Chang, Roberto and Andres Velasco, 1999, "Liquidity Crises in Emerging Markets: Theory and Policy", working paper, federal Reserve Bank of Atlanta.

Demirguc-Kunt, Asli and Enrica Detragiache, 1999, "The Determinants of Banking Crises in Developing and Developed Countries", IMF Staff Papers.

Diamond, D. W. [1999], “Should Japanese Banks Be Recapitalized?” University of Chicago working paper.

Diamond, D. W. and P. H. Dybvig [1983], "Bank Runs, Deposit Insurance, and Liquidity," Journal of Political Economy 91, 401-419. 
Diamond, D. and R. Rajan [1999], "Liquidity risk, liquidity creation and financial fragility: A theory of banking", mimeo, University of Chicago.

Diamond, D. W. and R. G. Rajan [2000a], “A Theory of Bank Capital,” forthcoming, Journal of Finance.

Diamond, D. and R. Rajan [2000b], “Aggregate Liquidity Shortages and Banking Crises”, in progress, University of Chicago.

Dooley, Michael, and Insook Shin [1999], "Private Inflows when Crises are Anticipated: A Case Study of Korea", mimeo.

Hart, Oliver and John Moore, "A Theory of Debt Based on the Inalienability of Human Capital," Quarterly Journal of Economics, v109 n4 (November 1994), pp. 841-79.

Holmström, B. and J. Tirole [1997], "Financial Intermediation, Loanable Funds, and the Real Sector," Quarterly Journal of Economics, 52 (August): 663-692.

Johnson, Simon, Peter Boone, Alasdair Breach, and Eric Friedman (1999), "Corporate Governance in the Asian Financial Crisis: 1997-98”, forthcoming, Journal of Financial Economics.

Kaminsky, Graciela, and Carmen Reinhart, (1999), "The Twin Crises: The Causes of Banking and Balanceof-Payment problems", American Economic Review, vol 89, 3, 473-500

Kashyap, A., R. Rajan, and J. Stein [1999], "Banks as Liquidity Providers: An Explanation for the Co-Existence of Lending and Deposit Taking", mimeo, University of Chicago.

Krugman, Paul (1998), "What Happened to Asia", mimeo, M.I.T.

Lane, Timothy, Atish Ghosh, Javier Hamann, Steven Phillips, Marianne Schulze-Ghattas, and Tsidi Tsikata, "IMF supported programs in Indonesia, Korea, and Thailand: A preliminary Assessment", mimeo, International Monetary Fund.

Myers, Stewart and Raghuram Rajan (1998), "The Paradox of Liquidity", Quarterly Journal of Economics, August 1998, vol 113: (3), pp 733-771.

Pomerleano, Michael (1998), "The East Asian Crisis and Corporate Finances - The Untold Micro Story", Emerging Markets Quarterly.

Radelet, Steven and Jeffrey Sachs (1998), "The East Asian Financial Crisis: Diagnosis, Remedies, Prospects", mimeo, Harvard Institute for International Development.

Rajan, Raghuram and Luigi Zingales, (1998), "Which Capitalism: Lessons from the Asian Crisis", Journal of Applied Corporate Finance.

Smith, Bruce (1991), Bank Panics, Suspensions, and Geography: Some Notes on the "Contagion of Fear" in Banking, Economic Inquiry; v29 n2 April 1991, pp. 230-48. 


\section{Figure 1}

\section{Bargaining at date 1 or 2 between a lender and entrepreneur}

At date 2 there is no future output or future liquidation right remaining.

Entrepreneur offers an alternative current and future financial contract. Entrepreneur will supply current human capital and make the alternative current payment if and only if agreement is reached.

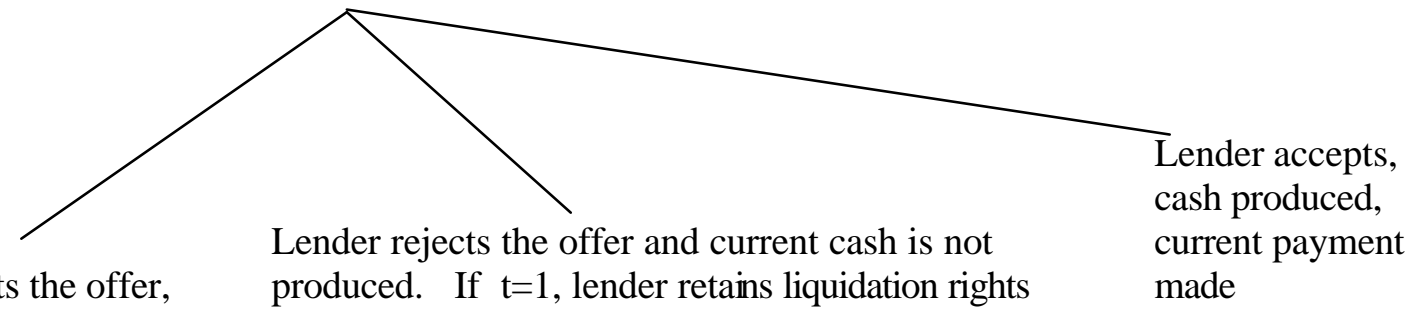

Lender rejects the offer, liquidates for $\gamma \mathrm{C}$ if the project is early (or for 0 if not the relationship lender)

This destroys all future output. to liquidate for $\gamma \mathrm{C}$ at date 2 if project is late (for 0

if not the relationship lender). 
Figure 2

\section{Bargaining at date 1 or 2 between a relationship lender and her creditor}

Relationship lender (R. Lender) offers to supply current human capital to negotiate this period with the entrepreneur if and only if creditor agrees to a fee she proposes.

Creditor rejects the offer, and will enter into negotiation with entrepreneur (see figure 1). Relationship lender gets zero today.

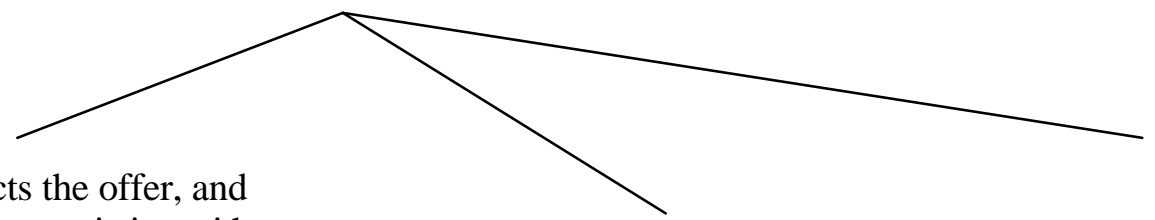

Creditor rejects the offer and enters into negotiation with relationship lender
Creditor accepts

R.lender negotiates with entrepreneur (see figure 1)

\begin{tabular}{|c|c|c|c|}
\hline $\begin{array}{l}\text { R. lender } \\
\text { accepts and } \\
\text { negotiates } \\
\text { with }\end{array}$ & R. lender rejects & $\begin{array}{l}\text { Creditor } \\
\text { accepts } \\
\text { R. lender } \\
\text { negotiates }\end{array}$ & Creditor rejects \\
\hline entrepreneur & $\begin{array}{l}\text { Creditor enters into current } \\
\text { negotiation with entrepreneur } \\
\text { (see figure 1). Relationship } \\
\text { lender gets zero. }\end{array}$ & $\begin{array}{l}\text { with } \\
\text { entrepreneur }\end{array}$ & $\begin{array}{l}\text { Creditor enters into current } \\
\text { negotiation with } \\
\text { entrepreneur (see figure 1). } \\
\text { Relationship lender gets } \\
\text { zero. }\end{array}$ \\
\hline
\end{tabular}


Figure 3: Local lending by foreign banks with domestic operations (as share of total cross-border claims)

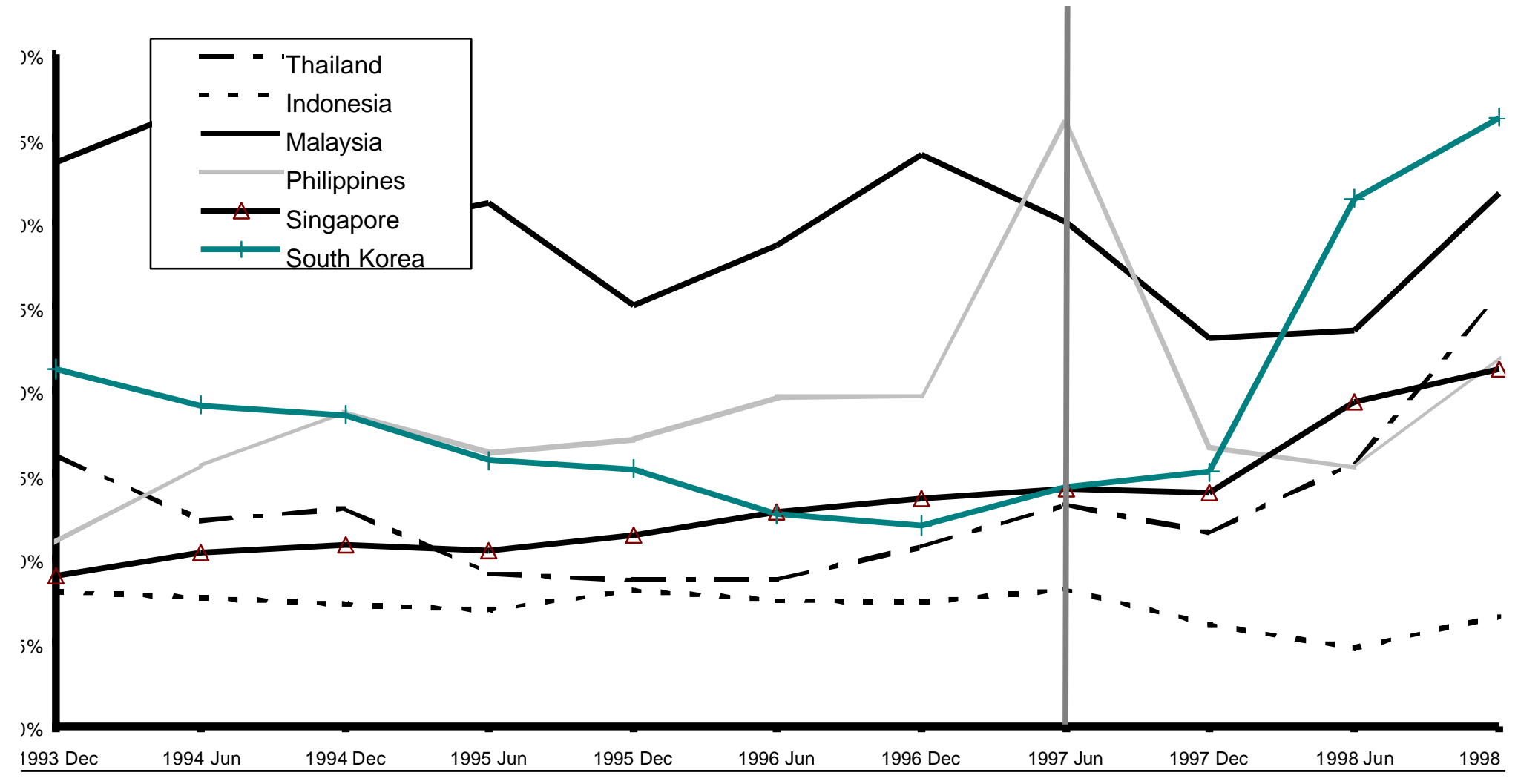

